voluntarily or not. Despite the strong tendencies for states to privatise military operations, there are core areas inappropriate for privatisation. The use of force by states is one of these areas. Using PMCs for support or protection in conflicts is one thing, but using them on the front line goes too far. The rules of international humanitarian law applicable to employees of PMCs show that there is a limit to their involvement in combat operations. It is imperative that these rules and responsibilities be taught to the PMCs themselves, but also and in particular to every employee of a PMC.

\title{
Private Military and Security Companies, the European Union, and Regulation as a Tool for Efficiency
}

\author{
Alyson J.K. Bailes*
}

\begin{abstract}
Some European nations both host and use private military and security companies as a solution to the rising demand for overseas operations at a time when they have shrinking defence assets. However, other nations refuse to legitimise this process and the European regulatory structure is weak. Outsourcing to PMSCs can lead to economic abuses and loss of efficiency as well as misconduct. Remedies require a mix of hard and soft regulation, good contract drafting, and supervision. European performance might benefit from seeking common solutions of this kind in the ESDP framework.
\end{abstract}

Keywords: Private military and security companies (PMSCs), European Union, privatisation, peace missions, defence economics

$\mathrm{T}$ he European countries in NATO and the European Union (EU) today who want to contribute to peace missions are caught on the horns of a dilemma between the desire to meet the demand and the capacity to meet it. They often have national reasons for action - peacekeeping/humanitarian traditions, an exportable 'surplus' of security since the Cold War, historical/cultural links with conflict hotspots - and NATO and the EU themselves have set very explicit targets for the quantity and quality of their efforts. At the same time their defence budgets are overstretched and manpower is often a problem, not least because so many states are being driven towards abandoning conscription. Moreover, while several countries faced lighter or simpler military burdens during the Cold War because of their peripheral location, small size, and/or neutrality, today's demands for military participation - being largely de-territorialised - fall upon literally everyone and frequently force the smaller states to make the most difficult choices.

Supply and demand is also the underlying cause of the recent increase in the use of private military and security companies (PMSCs), especially by 'strong' and democratic states. PMSCs offer such states a way to get jobs done (and get credit for them) that they are not prepared to do with their own forces. Such 'overspill' tasks may be less specialised, not demanding 'core' military expertise; or they may need to go on for longer than the state's forces are prepared to stay; or (notoriously, though not typically) they may appear too risky or even potentially discreditable. They are wide-ranging, going from innocuous services like food and laundry for troops at home, through the hire of air- and sea-lift or specialised equipment, to non-combat services in the field, 'peaceful' military services like aid de- livery or training local militaries, guarding persons and sites, and finally the controversial options of private intelligence gathering, policing or prison management, and actual combat tasks. ${ }^{1}$ The decision to 'privatise' 2 a given function in a given case always has a resource rationale in the broad sense that it appears more efficient/appropriate/sustainable than using state assets; and the decision-makers may also believe that it will be less expensive at least in the immediate term. The two points are distinct because it may make sense for a state to buy a service that costs more than using its own personnel if state assets are simply not available, or using them could cause more political and managerial problems, or if it wants to keep them for a task that has a higher priority. The issue of what constitutes a fair price premium in such a case is considered below.

The extent to which European states have resorted to such solutions is hard to document precisely, but some patterns can be detected. First, as regards companies being based in Europe: firms supplying security services such as physical security advice and equipment, guarding, and the transport of valuables exist throughout the EU and have for some time had their own trade association, the Confederation of European Security Services (CoESS - website: http://www.coess.org). Military service companies are mainly concentrated at the Western and Eastern ends of Europe - particularly in the UK, France, and various post-Communist countries including Russia itself. They are

* Alyson J.K. Bailes is a Visiting Professor at the University of Iceland and a former Director of the Stockholm International Peace Research Institute (SIPRI) The views expressed here are entirely her own.

1 For more on this and the general analysis of PMSCs see Holmqvist, C., 'Private Security Companies: the case for regulation', SIPRI Policy Paper No 9, January 2003, text at http://www.sipri.org.

2 The word 'privatise' is used here only as shorthand; the problems and pitfalls associated with its definition are explored in the next section. 
more likely to have links with the defence industry proper, and include some large firms which - on a pattern increasingly common in the USA - combine services with equipment sales, maintenance and/or consultancy. ${ }^{3}$ In terms of officially resorting to the use of PMSCs, again the UK stands out as having used companies rather liberally especially when operating abroad. ${ }^{4}$ This reflects the scale of its global actions and responsibilities, but also perhaps British pragmatism, the confidence that a large military establishment may feel about mastering and controlling the private tool, and the value of native companies' earnings. Several medium and smaller states including the globally active Nordic countries ${ }^{5}$ have experimented with private services for their own troops at home and during training, but are more conservative about using them abroad except perhaps for the personal protection of civilians. Other countries again resist any defence-related outsourcing at all, because of sensitivities about the alienation of state responsibilities, the idea of 'mercenaries', or traumatic past experiences. However, no militarily active European state can avoid the occasional purchase of enabling services such as air- and sea-lift. Furthermore, like the UN, the EU's own staffs have sometimes hired private protection services for their representatives operating in conflict zones or used private help in logistics for ESDP missions.

The aim of this article is to explore further the obstacles to, and difficulties of, using PMSCs in a specifically European context, and to survey some possible solutions. Unlike many other commentaries on PMSC regulation, it aims to probe the issue of efficiency (or more broadly, correct resource use) in this context as much as or more than the challenge of potential violence and human rights offences. It closes with a session speculating on the handling of PMSC use in the framework of ESDP.

\section{European regulation or the lack thereof}

The European record on regulation is relatively poor. ${ }^{6}$ National norms do exist for non-military security services at home, but (despite much lobbying) the European Commission has not yet sought to draft an internal market regulation setting Europe-wide standards. Other EU measures adopted mainly in the framework of the Common Foreign and Security Policy (CFSP)

3 In 2005, 7 of the 100 largest-selling defence companies in the world were ones that heavily specialised in 'homeland security' products and services (Sköns, E. and Surry, E.A., 'Arms production' in SIPRI Yearbook 2007: Armaments, Disarmament and International Security, Oxford University Press: Oxford, July 2007, pp. 345-373). For further references on defence industry development and services see Dunne, P. and Surry, E.A., 'Arms production' in the equivalent SIPRI Yearbook for 2006, pp. 415-416.

4 France is more often cited as a base for private activity by such companies as Secopex and Défense Conseil International, the latter having a $49.9 \%$ state shareholding; on the other hand it has passed national legislation to curb French-based 'mercenarism' (law of 14 April 2003). It remains to be seen whether latest planned cuts in French active forces will mean more active outsourcing by the French state itself.

5 For a survey of the experience of outsourcing by four Nordic states see Østerud, $\varnothing$. and Matláry, J.H., Denationalisation of Defence: convergence and diversity, Ashgate, London, 2007. Planning for the Nordic Battle Group in the ESDP context has included exploration of options for private lift

6 Three general studies on this topic are Krahmann, E., 'Regulating Private Military Companies: What Role for the EU?', Contemporary Security Policy, vol.26, no.1 (2005); Krahmann, E., 'Regulating military and security services in the European Union' in (eds.) Caparini, M. and Bryden, A., Private Actors and Security Governance (Berlin: LIT Verlag, 2006); and Bailes, A.J.K. and Holmqvist, C., 'The Increasing Role of Private Military and Security Companies', commissioned and published by the European Parliament Oct. 2007 (see http://europarl.europa.eu). have captured certain specialised aspects of private activity such as the servicing of equipment - and certain abuses - such as arms trafficking or the export of instruments of torture by private operators - as it were en passant in the process of trying to discipline governments and other kinds of non-state actors. (A list of some key EU instruments appears in Table 1 below). The picture on national legislation for military service companies is mostly thin: Sweden is the only EU member to control all service exports in the same way as arms exports - which happens to be also the basis of the USA's national approach. ${ }^{7}$ The UK got as far as a 'Green Paper' in 2002 outlining options for regulation including a case-by-case licensing system, but failed to proceed to actual legislation. By contrast, efforts at self-regulation by the industry have been above all active in the UK: the British Association of Private Security Companies (website at http://www.bapsc.org.uk) has united the larger British companies on a platform of corporate responsibility and openness and is now taking the lead in setting up a Europe-wide industry association.

It is worth probing these gaps and deficiencies a bit further, since any drive for better regulation must find a way through or around them. Reaching a consensus among 27 EU member states whose national attitudes are as diverse as those described above is the most obvious difficulty. The states and non-state lobbyists who are most antipathetic to private companies have often rejected attempts at regulation on the grounds that to bring such actors within the law is to 'legitimise them'. Underlying this distinctly European view ${ }^{8}$ may be the fact that Europe is the continent which longest ago and most definitively switched to a system of state-owned national armies: thus the notion of a state monopoly of military assets is deep-rooted and the idea of the state legislatively 'recognising' non-state bearers of arms can seem to be both constitutionally and morally perverse.

Each of the major Europe-based organisations has its drawbacks as a framework for rule-making on PMSCs. The Organization for Security and Cooperation in Europe (OSCE) deals with ethical and governance-related as well as security aspects of military activity, but its family of states is much larger again than the EU's, and more divided, and it can only take politically binding decisions. NATO also lacks legislative, economic and commercial competence; since the 1990s it has effectively ceded the lead even in defence industry policy making to the EU. The EU is an organ for market regulation and sectoral policy making par excellence, and took a decisive step into planning and standard-setting for the armaments sector in 2004 with the creation of the European Defence Agency (EDA). However, its member states still cling to the provision - currently Article 296 of the Treaty on European Union - that exempts national defence

\footnotetext{
7 In Swedish law companies are not prevented from re-locating abroad in order to deliver armed services. The US system treats services as equally subject with hardware to licensing under the International Trafficking in Arms Regulation (ITAR), but its effectiveness is open to question: see Caparini, M., 'Domestic regulation: Licensing regimes for the export of military goods and services', in Chesterman, S. and Lehnardt, C. (eds.), From Mercenary to Market: the Rise and Regulation of Private Military Companies (Oxford: Oxford University Press, 2007).

8 South Africa also strongly opposes PMSCs but has passed detailed legislation precisely in order to make it harder for them to exist in the country or employ its citizens: here regulation is used to de-legitimise most such activity.
} 
transactions from the normal rules of the Single Market and from Treaty provisions generally. The effect has been to block the use of Community regulations (i.e. laws based on proposals by the European Commission and capable of taking direct legal effect within member states) for anything that concerns military activities within the EU's territory. The same applies to imports of equipment or services. The bulk of measures ${ }^{9}$ that have been taken to guide the export or external use of military equipment, on security and/or humanitarian grounds - notably the EU Code of Conduct on conventional arms exports (see Fig.1) - have been adopted as inter-governmental decisions in the framework of CFSP, which makes them politically rather than legally binding and not justiciable by the European Court of Justice..$^{10}$ Interestingly, it is the European Parliament that has been most persistent in urging the other Brussels institutions to overcome these gaps and blockages so that, if nothing else, the EU organs' own use of private services can be rationalised. delegated and re-delegated tasks to subordinates who are worse paid, less competent to deliver, and often impossible for the authorities to trace and hold to account. Investigations by Congress and the audit authorities in the USA have unmasked abuses amounting to billions of US dollars. ${ }^{11}$ Context, causes and possible remedies for this aspect of the PMSC challenge have not been discussed much in the literature: yet since a resource rationale (see above) often drives the stronger governments' decision to resort to them, a resource-oriented critique could bring ammunition both for those who would like to abolish and those who would prefer to reform them.

Before looking more closely at the use of PMSCs as a resource transaction, however, it is important to be clear about what kind of transaction it is. The term 'privatisation of security', which is often used to link the rise of PMSCs with other shifts in power from states to private actors (and/or to market forces),

Table 1: Summary of EU Regulations and Decisions Covering Private Defence-related Services

\begin{tabular}{|c|c|}
\hline \multicolumn{2}{|l|}{ Legally binding regulations } \\
\hline EU Council Regulation 1334/2000 & Control and licensing of the export of 'dual-use' goods inc. related services \\
\hline EU Council Regulation 1236/2005 & Export ban on goods/services designed for capital punishment and torture \\
\hline \multicolumn{2}{|l|}{ CFSP, explicitly targeting private actions } \\
\hline $\begin{array}{l}\text { EU Council Common Position 2003/469/CFSP, } \\
\text { June } 2003\end{array}$ & $\begin{array}{l}\text { Requires member states (MS) to control arms brokering taking place from } \\
\text { their territory }\end{array}$ \\
\hline \multicolumn{2}{|l|}{ Other CFSP } \\
\hline Council Joint Action 2100/401, 22 June 2000 & Requires MS to control supply of technical services related to WMD \\
\hline Ad hoc Council decisions & Embargoes on arms exports and related services to specified states \\
\hline $\begin{array}{l}\text { EU Code of Conduct on Armaments Exports, } 5 \text { June } \\
1998\end{array}$ & $\begin{array}{l}\text { Requires MS to control, by licensing, arms exports and (if wished) services } \\
\text { according to } 7 \text { principles of restraint }\end{array}$ \\
\hline EU Council Joint Action 2002/589/CFSP & Requires action to stem trade in small arms and light weapons \\
\hline
\end{tabular}

\section{Outsourcing, cost and efficiency}

The best-known cases of recent employment of PMSCs are those that have turned out worst, especially in the context of the highly mediatised conflicts in Afghanistan and Iraq. Most shocking are those involving brutality and human rights abuses; or, on the other side, poor practices and legal vagueness that may have led to unnecessary deaths among contracted personnel and a lack of redress for their families. However, there are also ample cases of purely commercial irregularities, below-standard service delivery and other bad business practice. Private companies have demanded extortionate prices for some quite ordinary (e.g. logistics and supply) services, then

9 The only significant Community Regulations in this field apply to the export of dual-use (i.e. mainly or partly civilian) goods and technologies related to Weapons of Mass Destruction, and of instruments of torture, respectively -i.e. in neither case to mainstream military equipment (see Fig. 1).

10 The idea of converting the Code of Conduct into a legally binding instrument has, however, been under discussion for quite some time and is currently opposed by a minority of states. A recent ruling by the European Court of Justice that the Council cannot take away the Commission's competence to make policy on small arms might also lead to new legislative ventures in that field. is at best a time-saving shorthand. It does not match the way the word is used in other areas of public policy, and does not help much in identifying the real issues of value and responsibility. In the fields of commerce, industry and infrastructure a state privatises an asset when it transfers it to a non-state owner, and privatises a service when it similarly transfers the right to execute it. Neither transaction is commonly reversible and if there are public interests such as safety factors involved, the state's main recourse is to set standards and boundaries for the private operators through regulation (or steer them indirectly e.g. through taxation policies.

When strong states use PMSC services, they are neither transferring property to the companies nor permanently transferring parts of their defence and security competence. Services

11 The Congressional investigation has taken place in the House of Representatives Committee on Oversight and Government Reform, see http://www. oversight.house.gov/investigations.asp?Issue=Iraq+Reconstruction. It is fair to add that similar or larger financial abuses have been uncovered in the case of civil contracts (e.g. for construction) involving other types of US or local companies, and that large cost overruns seem endemic in the armaments industry proper. 
purchased for operations abroad are by definition ad hoc and finite in their aims (like the operation itself); and they are generally specialised and partial - picking up non-'core' aspects of the mission or functions needing less government expertise. Meanwhile, the state may still be performing the delegated functions itself in a different location. The definitions best fitting this phenomenon are 'outsourcing' and 'delegating' (from the viewpoint of the purchasing authority), or (for the transaction as a whole) the 'purchase' of services or 'loan' of manpower and assets. ${ }^{12}$ This definition leads more directly to the key questions on effectiveness: (a) are there certain things that should never be delegated; (b) is the second-hand (or 'proxy') delivery of certain functions inherently less efficient; and, (c) where a function can rationally be delegated, how can that be done properly and at a fair price?

\section{Limits, drawbacks and guidelines for out- sourcing}

The notion of a no-go area in defence work where a state should not knowingly alienate its functions, even as a matter of temporary delegation, is not at present a matter of international law but is widely supported on political and moral grounds. (Clear answers on this point would also help define the minimum of core state functions needing to be restored to the centre in weak and failed states.) Obvious rules could include not ceding the command of state forces to private users - which some developing countries have been known to do for guarding large companies - or using private agents for executing justice including the death penalty, if any. Many would oppose using companies in any 'combat' function at all, or for the interrogation and the operation of prisons and detention facilities. A strong question mark on efficiency grounds also applies to using private companies for intelligence gathering and analysis. Business people have valuable knowledge and expertise to be garnered during official intelligence work, but letting them take over the whole collation and analysis process - especially during a conflict - has borne poor results in practice. The skill that firms possess in processing security information for commercial clients is often ill-adapted to the different targets and needs of a state user, and without deep local knowledge of each venue they are at risk of superficial and hasty judgments. Also, it should be obvious that a company will be very tempted to exaggerate risks and demands that will prompt the state employer to buy even more of its services. ${ }^{13}$

If a state can correctly define the range of functions that it may delegate without major political or moral hazard, the agenda shifts to the question of efficiency proper. Here there are a number of general pitfalls in using commercial intermediaries,

12 Successful experiments with private supply of non-military support services for troops at home approach closer to real privatisation mainly because they are not likely to be reversed. However, since the services being provided are of a civilian and generic nature, these cases arguably raise even fewer issues of principle than relying on industry for military equipment supplies.

13 It would also be worth exploring the thesis that the number of private operators employed on a task should not rise above a certain proportion of total manpower allocated by the state: thus, if a government lacks the necessary 'own resources' to put a clear governmental stamp on a particular exercise of military powers, it should simply not embark on it. The exercise of such prudence would have made an obvious difference in Iraq. above all in overseas situations where their performance affects the interests not just of the employer but also of the local population (and of other actors operating alongside them):

- the problem of control of their activities, for all purposes including effectiveness and general behaviour as well as avoidance of abuses: this is hard because the employer is short of manpower to start with, and it is especially hard when firms are 'left behind' e.g., to carry out reconstruction duties;

- the problem of market-controlled supply, which may mean that a state cannot find enough commercial resources at the point when it needs them (this often happens with lift assets) or ends up with little or no choice of alternative suppliers. The current tendency towards concentration in the Western part of the PMSC industry also reduces the chances for customers to benefit from healthy competition;

- the problem of command and discipline, which means i.a. that a company may choose to simply break the contract and withdraw if it deems that the conditions have become too difficult;

- difficulties of coordination between PMSCs and other state, institutional and non-state operators within a given conflict or post-conflict scene: this can be hard because of confusion over who the private actors are and what they are supposed to be doing, because of confidentiality problems on the official side, and because of anti-PMSC attitudes among many NGOs;

- the problem of reduced contact for the state provider with the local environment (compared with direct state action), notably with the recipients of positive services like aid delivery and training. In more traditional relationships between visiting forces and local actors, state learns from state and there is a chance to build relations based on understanding, gratitude and solidarity that can turn into major security-policy assets for the future;

- the difficulty of price-setting where the only alternative to private supply is a government-delivered function that has mostly hidden costs, where competition among suppliers is limited and imperfect, and where the customer may have to pay a premium not just to get services in a risky setting but to get them from a relatively reliable partner. When the price is excessive this not only undermines the overall efficiency of the transaction, but means that the company can buy out the cream of local support staff at a price far higher than what official and institutional actors can offer. Goodquality regular soldiers are often also lured away by the lavish conditions (not just higher pay) offered by PMSCs;

- the problem of (unlicensed and uncontrolled) sub-contracting by the company that was initially employed to other suppliers, both foreign and local, which aggravates problems of quality and control but also makes the transaction less efficient by creaming off profit at several levels.

The range of remedies a state (or institution) may use to resolve these problems forms a special set within the range of the options available for all market-based outsourcing and delegation to private actors: namely prohibition (already discussed), regulation, case-by-case executive control, self-regulation and ongoing liaison. In the present case, 
i) regulation could be applied to companies that are based on the state's own territory, to individuals holding the state's nationality regardless of where they act, ${ }^{14}$ or to foreign companies acting on the national territory. ${ }^{15}$ Key targets for such rules would be standards for transparency of ownership, operations and finance, minimum qualifications and training requirements for staff, etc; plus general provisions on responsibility for observing national and international legal codes, on judicial answerability, and adjudication of allegations or disputes ${ }^{16}$.

ii) The crucial tool for executive control is the contract, where the state can repeat the above provisions so as to impose them on any foreign and/or native firms it may employ; can set performance standards including penalties for under-performance and breach of contract; can define quality monitoring systems (possibly with an element of feedback from local 'customers'), and can seek to control sub-contracting, e.g. by limiting how it can be used or making it subject to the original purchaser's consent. Of course, in selecting the company that is to be awarded the contract a state also can and indeed should look at performance and credentials and apply 'black lists' or 'white lists'.

iii) Self-regulation is never enough on its own but can be helpful as an adjunct not least because firms' attitude to it is a prima facie guide to their (desire for) respectability. The large associations specifically hope that their codes will help drive smaller and shadier competitors out of the market. A company can also be challenged for breaching its own principles even when these are not matters of law. ${ }^{17}$

iv) Transparent and regular arrangements for review and consultation between purchasers and companies over contract execution, plus a 'panic button' for urgent issues should, in principle, nip problems of under-performance, 'mission creep', wrongful subcontracting and so forth in the bud, as well as palliating the 'reduced contact " problem mentioned above. In some notorious US cases this type of oversight was almost wholly abandoned following the granting of 'indefinite duration, indefinite quantity' contracts to a single supplier over several years. ${ }^{18}$

Such prescriptions may sound inadequate set against the scale and often shocking nature of PMSC mismanagement that has been reported in recent years. However, these worst cases can almost always be traced either to company use in weak states where such controls were unenforceable, or to cases - notably in Iraq and Afghanistan - where 'strong state' employers failed to apply them properly due to haste, amateurishness, irrespon-

14 This is still an unusual method for regulating the private services sector but has been applied e.g. in a UK law making UK citizens answerable for child prostitution and pornography offences no matter where in the world the crimes are committed.

15 This last approach can of course be applied by countries in other regions where European companies operate. A combination of at least the first and third of these approaches is by far the strongest because it reduces the incentive and scope for companies to escape control by simply shifting their domicile.

16 The BAPSC has suggested using an Ombudsman for this last purpose.

17 The code created by the BAPSC for its members largely concerns transparency, selectiveness about employers and good conduct, but includes some references to respecting professional standards defined e.g. by the International Standards Organization (ISO) and British standards authorities (BS). See the BAPSC self-assessment workbook, available at http://www.bapsc.org.uk/key documents-membership_criteria.asp.

18 See Holmqvist, as note 4 above, p. 31 . sibility or complicity in corruption. ${ }^{19}$ In recent US operations, a climate where cash seemed unlimited clearly aggravated the problem. If cash-strapped European employers had not discovered ways to get better value out of their own more modest outsourcing ventures, it is hard to see why they are persisting with them and even expanding the practice as is the case.

\section{ESDP and outsourcing}

Assuming that at least some European PMSCs could be employed with reasonable confidence about their conduct and efficiency - which would also depend on the EU playing its part in enacting the more normative kind of controls not discussed here - how precisely might they ease Europeans' collective resource problems in ESDP? First, if the EU's own organs could continue and modestly expand their direct contracting of non-state services this would reduce the demands they have to pass on to states during force generation processes. Secondly, member states could use them more freely for providing active personnel services (not just enabling assets) within their own deployed force contributions. The formal acceptance of such use by the EU, combined with collective endorsement of a minimum standard (leaving room for even stricter national solutions) for PMSC-related controls, would ease the integration of and coordination between the contingents from different member states who at present have different PMSC-related policies. It would become easier for nations preparing and exercising an EU Battle Group together to include suitable elements of outsourcing in their joint plans. Third, the delegation of some post-conflict functions (such as local training) to reliable companies could provide an intermediate step towards full localisation and allow a somewhat earlier exit of EU personnel. ${ }^{20}$ Finally, as several countries have already found, the outsourcing of banal and essentially civilian services - or dual-use tasks like driving and flying instruction - for the forces back home should allow the latter to be focused more exclusively on core military tasks and on gaining core military skills, thus i.a. releasing more manpower for overseas deployment.

ESDP is managed within the EU Council system by inter-governmental decisions, so any ESDP-specific EU initiatives would take an executive and politically binding form. A starting point would be to commission a study of current European PMSC use and experiences with the focus on identifying best practice and the keys to cost-effectiveness, covering domestic outsourcing as well as the 'sexier' issue of private services in the field. Another much-felt need is a list of what should be defined as 'security' and 'military' services respectively, just as the EU's arms export Code is based on an agreed equipment list. Such a tool would be

19 A good example is the Blackwater company which has not only been implicated in flagrant acts of excess violence in Iraq, but has also been the subject of claims of presenting excessive costs and charges, both problems being linked with obscure lines of contracting and inadequate state control: thus Congress was told in February 2007 that the costs of Blackwater private security employees who were paid US $\$ 500$ per day, were billed to the contractor at $\$ 1,100$ 1,500 per day implying an annual cost per head of $\$ 400-540,000$ compared with an Army Sergeant's pay of \$51-69,000. See the Congressional website in note 11 above.

20 In the case of EU assistance missions where officially-provided teams may be made up of small numbers of experts from 20 or more states with widely different standards, a good PMSC could arguably provide more coherence and professionalism! 
needed for introducing any EU-wide or EU-standard system of licensing, for companies themselves and/or individual exports of services - which is often discussed as a way to reduce abuses but should in fact also ensure more reliable performance. A third object of study could be a proposed set of 'no-go areas' for outsourcing; a fourth could be a model form of contract on which some work has already been done ${ }^{21}$; a fifth could be the building of white lists and black lists based on company performance; and sixth could be a suggested set of operational rules for accommodating privately contracted personnel within EU operations (and in Battle Groups in preparation for them), including minimum standards of command and control, training, monitoring and dispute/allegation handling. Finally, it would be interesting to review the feasibility of some kind of agreed tariff to counteract exploitative pricing, or - perhaps more feasibly - long-term framework contracts with reputable companies including a fixed price-scale for the services commonly required.

The economic and industrial aspects of such research would go beyond the expertise of most Council employees, but an interesting option is now available in the shape of the European Defence Agency (EDA) whose duties include forecasting long-range industrial and technological trends. An alternative would be for a Presidency nation to offer the studies using its

21 Notably in the work of the Swiss Government-backed initiative on PMSC regulation, which has produced a model contract for contracting with PMSCs based on the Ordinance on the Use of Private Security Companies by the Federal Government. See: http://www.ejpd.admin.ch/etc/medialib/data/si cherheit/gesetzgebung/sicherheitsfirmen.Par.0007.File.tmp/modellvertragsicherheitsfirma-f.pdf own resources or an ad hoc international research team. Even starting the ball rolling on one or two of the above-mentioned points would be helpful. If the EU is going to be forced into outsourcing to manage ESDP's own unfeasible demands, it needs to do it in a responsible, consistent and street-smart way: and if after all it decides not to do so, it will need a clear collective explanation for its taxpayers.

\section{Conclusion}

The differing views and practices of different western nations on the employment of PMSCs are a possible source of friction between them, adding - for instance - a sometimes dramatic streak to European concerns about recent US military practice. They are, however, also an obstacle to the closer integration of multilateral force groups for peace missions and other tasks, both in the Euro-Atlantic context and in other regions of increasing security cooperation. There is a strong case for groups of countries that seek standardisation in other realms of defence, including the EU's member states in the ESDP context, to address this issue together. The aim should be to combine hard, soft and ad hoc methods of regulation to ensure value for money, as well as general good conduct in those fields and tasks where use of PMSCs is both ethically and politically permissible and rational in resource terms. The coincidence of timing with an effort by many European companies at self-regulation is useful and should be exploited to drive any 'rogues' out of the business, but this last aim also demands effective regulation by 'recipient' countries.

\title{
Sustainable Peace and Global Security Governance
}

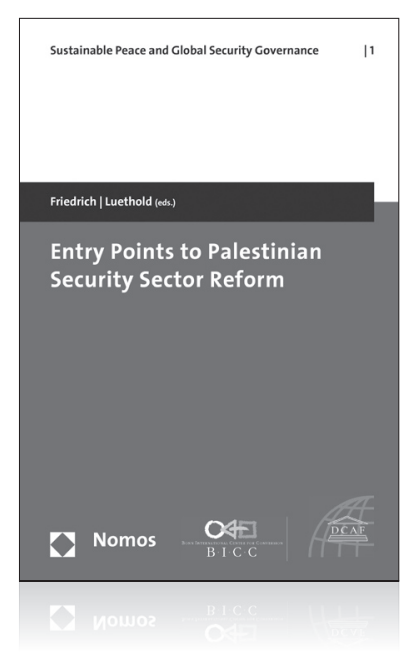

\author{
Entry-Points to Palestinian Security Sector Reform \\ Herausgegeben von Roland Friedrich und Arnold Luethold \\ 2008, Band 1, 150 S., brosch., 29,- €, ISBN 978-3-8329-3530-6
}

Die Reform des Sicherheitssektors in Palästina ist ein aktuell besonders dringliches Thema. Sicherheitsexperten aus Wissenschaft und Praxis unterbreiten in diesem Band konkrete Vorschläge zur Lösung der Probleme. 